\title{
Effects of leptin on gonadotropin secretion in juvenile female rat pituitary cells
}

Michiko Tezuka, Minoru Irahara, Koji Ogura, Machiko Kiyokawa, Takao Tamura, Toshiya Matsuzaki, Toshiyuki Yasui and Toshihiro Aono

Department of Obstetrics and Gynecology, University of Tokushima School of Medicine, 3-18-15, Kuramoto-cho, Tokushima, 770-8503, Japan

(Correspondence should be addressed to Michiko Tezuka Email: michiko@clin.med.tokushima-u.ac.jp)

\begin{abstract}
Objective: Leptin is an adipocyte-derived hormone, which is the product of the obese gene and it is thought to play important roles in pubertal development and maintenance of reproductive function in the female. In a study using adult male or female rats, it was found that leptin stimulated the secretion of gonadotropin directly from the pituitary in a dose-related manner. However, there is no study in juvenile female rats before puberty.

Methods: In this study, we cultured pituitary cells from 4-, 6- and 8-week-old female Wistar rats with leptin $\left(0-10^{-7} \mathrm{~mol} / \mathrm{l}\right)$ and gonadotropin-releasing hormone $(\mathrm{GnRH})\left(0\right.$ or $\left.10^{-8} \mathrm{~mol} / \mathrm{l}\right)$. Basal or GnRH-stimulated secretion of luteinizing hormone (LH) and follicle-stimulating hormone (FSH), and their synthesis within cells were determined by radioimmunoassay (RIA).

Results: Leptin induced bell-shaped dose-response curves of basal LH and FSH secretion from cultured cells of every age-group of rats studied. The most effective concentration of leptin on the basal secretion of LH and FSH from 6- and 8-week-old cultured pituitary cells was $10^{-10} \mathrm{~mol} / \mathrm{l}$. This leptin concentration was consistent with circulating physiological serum leptin levels at each age. As for juvenile 4-week-old pituitary cells, the most effective concentration was $10^{-11} \mathrm{~mol} / \mathrm{l}$ which was lower than that of 6- and 8-week-old rats. It was consistent with the circulating serum leptin levels of 4-week-old rats. Also, the synthesis and the GnRH-stimulated secretion of LH and FSH were effectively controlled by leptin at concentrations similar to the serum leptin levels of given ages. Conclusions: Leptin induced pituitary cells to synthesize and secrete both LH and FSH regardless of the presence or absence of GnRH. The concentration of leptin that induced the greatest synthesis and secretion of gonadotropins from pituitary cells changed around the pubertal period. The most effective leptin concentrations in each experiment were similar to the physiological serum leptin level at each animal age. These results indicate that leptin stimulates gonadotrophs not only in the pubertal and the mature period but also in the juvenile period before puberty. It is also conceivable that leptin may modulate the sensitivity of gonadotrophs until the appearance of GnRH stimulation, and may be the factor that brings about puberty onset.
\end{abstract}

European Journal of Endocrinology 146 261-266

\section{Introduction}

It is well-known that gonadotropin-releasing hormone $(\mathrm{GnRH})$ and gonadotropins are required for the onset of puberty (1). Once pulsatile GnRH secretion from the hypothalamus occurs, it raises serum gonadotropin levels gradually, thus inducing puberty. However, serum gonadotropin levels are already somewhat elevated during the juvenile period despite the absence of pulsatile GnRH secretion. The relatively high levels of gonadotropins in the juvenile period are probably due to stimulation by some factors that may render the pituitary gonadotroph cells ready for stimulation by GnRH. However, these mechanisms remain to be clarified.
It is clear that an adequate mass of adipose tissue is essential for the onset of puberty and maintenance of fertility. The classical studies by Kennedy (2) and Frisch and Revelle (3) established that the timing of sexual maturation is associated with body weight and composition. Zhang and collaborators (4) also showed that the increase of body weight is a fundamental factor for the onset of puberty. Leptin, a product of the obese gene, is secreted from adipocytes and plays an important role in the regulation of body weight and glucose metabolism. Serum leptin is related to the absolute amount of adipose tissue, body mass index or body weight and markedly increases in proportion to the degree of adiposity (5-8). Therefore, it is 
strongly suggested that the increase in serum leptin level is associated with the onset of puberty.

There is some evidence that leptin plays an important role in reproduction through the hypothalamuspituitary axis. Recently, $\mathrm{Yu}$ et al. demonstrated that leptin acts on the hypothalamus to stimulate the release of $\mathrm{GnRH}$, thereby triggering gonadotropin release $(9,10)$. The subsequent release of luteinizing hormone (LH) and follicle-stimulating hormone (FSH) stimulates the secretion of gonadal steroid hormones, leading to the maturation of the reproductive system and the induction of puberty. Recently, we also demonstrated that leptin stimulates gonadotropin secretion from 6-week-old female rat pituitary cells (11). Our data indicated that leptin also acts on the pituitary during the period of puberty, but the mechanism of gonadotropin secretion during the juvenile period remains unknown.

In the present study, we investigated the effects of leptin on the secretion of gonadotropin from cultured pituitary cells of juvenile female rats in order to clarify the mechanism of puberty onset.

\section{Materials and methods}

\section{Animals}

All experiments were conducted in accordance with the ethical standards established by the Committee on Animal Care and Use of the University of Tokushima. Wistar female rats were obtained from Charles River Japan, Co. (Yokohama, Japan). The weights of 4-, 6and 8-week-old female rats were 75-95 g, 130$145 \mathrm{~g}$ and $170-200 \mathrm{~g}$ respectively.

\section{Primary culture of rat anterior pituitary cells}

We cultured rat anterior pituitary cells using a previously reported method (12). Rats were decapitated and the pituitary was removed. Pituitaries were cut into small pieces and washed in Dulbecco's modified Eagle's medium (DMEM; Nissui Co.,Tokyo, Japan). The cells were then subjected to enzymatic dispersion for $45 \mathrm{~min}$ at $37^{\circ} \mathrm{C}$ using $0.25 \%$ trypsin and were then dissociated by pipetting with pancreatin at $37^{\circ} \mathrm{C}$ for $1 \mathrm{~min}$, according to the previously reported method $(9,10)$. These cells were seeded in DMEM containing $10 \%$ fetal bovine serum, plated on 24-well culture dishes (Falcon Plastics, Los Angeles, CA, USA) at a density of $10^{6}$ viable cells/well, and incubated for $48 \mathrm{~h}$. Cell cultures were maintained at $37^{\circ} \mathrm{C}$ under a mixture of $95 \%$ air and $5 \% \mathrm{CO}_{2}$ at $100 \%$ humidity for $48 \mathrm{~h}$.

After 48-h culture, the cells were washed 3 times with serum-free DMEM containing $0.1 \%$ bovine serum albumin and then incubated for $20 \mathrm{~h}$ in serum-free DMEM with leptin $\left(0-10^{-7} \mathrm{~mol} / \mathrm{l}\right)$ (Leptin Rat, Recombinant; R\&D Systems, Minneapolis, MN, USA).
To estimate basal gonadotropin secretion, the supernatants were collected and assayed by radioimmunoassay (RIA). The cells were then washed 3 times with serum-free DMEM, and then continuously incubated in DMEM containing the same concentrations of leptin as stated above with or without $10^{-8} \mathrm{~mol} / \mathrm{l}$ $\mathrm{GnRH}$ (Sigma, St Louis, MO, USA) for $4 \mathrm{~h}$ at $37^{\circ} \mathrm{C}$. The supernatants were collected and assayed by RIA to estimate the GnRH-stimulated LH and FSH secretion.

The cells were then washed with serum-free DMEM. One milliliter Triton-X was added, the cells were removed from the dishes with a rubber remover, and the samples were sonicated $(20 \mathrm{kHz}, 160 \mathrm{~W})$ at $30-\mathrm{s}$ intervals for $5 \mathrm{~min}$. They were collected and centrifuged at $10000 \mathrm{~g}$ for $10 \mathrm{~min}$ at $4{ }^{\circ} \mathrm{C}$. The supernatants were collected and assayed by RIA for intra-cellular content of gonadotropins in order to estimate $\mathrm{LH}$ and FSH synthesis.

\section{Measurement of hormones}

Concentrations of LH and FSH were measured by double-antibody RIA using the National Hormone and Pituitary Program (NHPP, USA) kits. The intraand interassay variations of $\mathrm{LH}$ were $3.8 \%$ and $5.2 \%$, and those of FSH were $4.6 \%$ and $5.8 \%$ respectively.

\section{Statistical analysis}

The significance of differences between the various leptin experimental groups of animals was assessed using Student's unpaired t-test. LH and FSH concentrations were expressed as the percentage of the control value (mean \pm s.E.M.). Moreover, the differences in the pattern of LH and FSH secretion curves among 4-, 6and 8-week-old cells were compared using two-way ANOVA.

\section{Results}

\section{Effects of leptin on basal LH and FSH secretion from cultured pituitary cells}

Figure 1 shows the effects of leptin on basal LH levels secreted from cultured pituitary cells into the culture medium for $24 \mathrm{~h}$. Leptin stimulated basal LH secretion at concentrations up to $10^{-11} \mathrm{~mol} / \mathrm{l}(623 \%, P<0.01$ vs control) in 4-week-old pituitary cells. However, the effect of leptin diminished at higher concentrations and the results formed a bell-shaped dose-response curve (Fig. 1A).

Six- and eight-week-old cells also showed the bellshaped dose-response curves (Fig. 1B and C). However, the concentration of leptin which induced the greatest basal LH secretion at these ages was $10^{-10} \mathrm{~mol} / \mathrm{l}$, and the increases in LH secretion were lower than that observed in 4-week-old cells (191\% and 208\% respectively; $P<0.01$ vs control). 


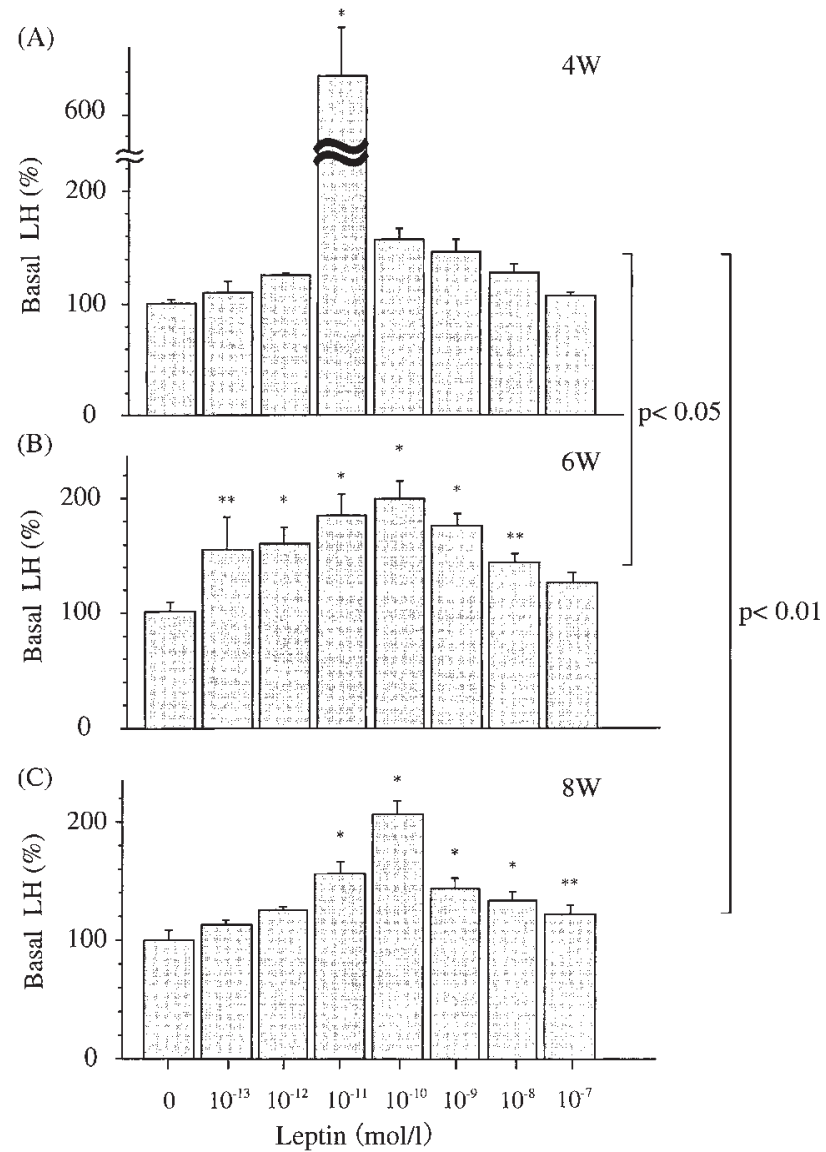

Figure 1 Effects of leptin $\left(0-10^{-7} \mathrm{~mol} / \mathrm{l}\right)$ on basal LH secretion from pituitary cells incubated in vitro for $24 \mathrm{~h}(n=8)$. (A) Fourweek-old pituitary cells. Basal LH levels exhibited a bell-shaped dose-response curve. The control level of LH (leptin free) was $35.3 \pm 0.76$ (mean \pm S.E.M.) IU/l. The peak level markedly increased as the concentration of leptin increased to $10^{-11} \mathrm{~mol} / \mathrm{l}(623 \%$; $P<0.01$ vs control). (B) Six-week-old cells. (C) Eight-week-old cells. LH levels in these two groups also exhibited bell-shaped dose-response curves. The control levels of LH (leptin free) in 6and 8-week-old cells were $30.8 \pm 1.81$ and 18.0 \pm 1.77 (means \pm S.E.M.) IU/I respectively. They gradually increased as the concentration of leptin increased, reaching a peak value at a concentration of $10^{-10} \mathrm{~mol} / \mathrm{l}$ (191 and $208 \%$ respectively; $P<0.01$ vs control). The concentration of leptin which brought maximum secretion of LH changed from $10^{-11} \mathrm{~mol} / \mathrm{l}$ to $10^{-10} \mathrm{~mol} / \mathrm{I}$ as the ages of rats changed from the prepubertal period $(A)$ to the pubertal $(B)$ and adult $(C)$ periods. There were significant differences in the shape of the curves between $(A)$ and $(B)$ and between $(\mathrm{A})$ and $(\mathrm{C})$. $(P<0.05, P<0.01$ respectively by twoway ANOVA). Results are expressed as percentage of the control value (mean \pm S.E.M.); ${ }^{*} P<0.01,{ }^{* *} P<0.05$.

Basal FSH secretion from 4-week-old pituitary cells was stimulated at leptin concentrations up to $10^{-11} \mathrm{~mol} / \mathrm{l}(224 \%, P<0.01 \mathrm{vs}$ control $)$. The effects of leptin on FSH secretion from 6- and 8-week-old cells were increased by leptin at concentrations up to $10^{-10} \mathrm{~mol} / \mathrm{l}(139 \%$ and $147 \%$ respectively; $P<0.05$ and $P<0.01$ vs control). However, at higher concentrations, these effects diminished in all age groups (Fig. 2A, B, C).

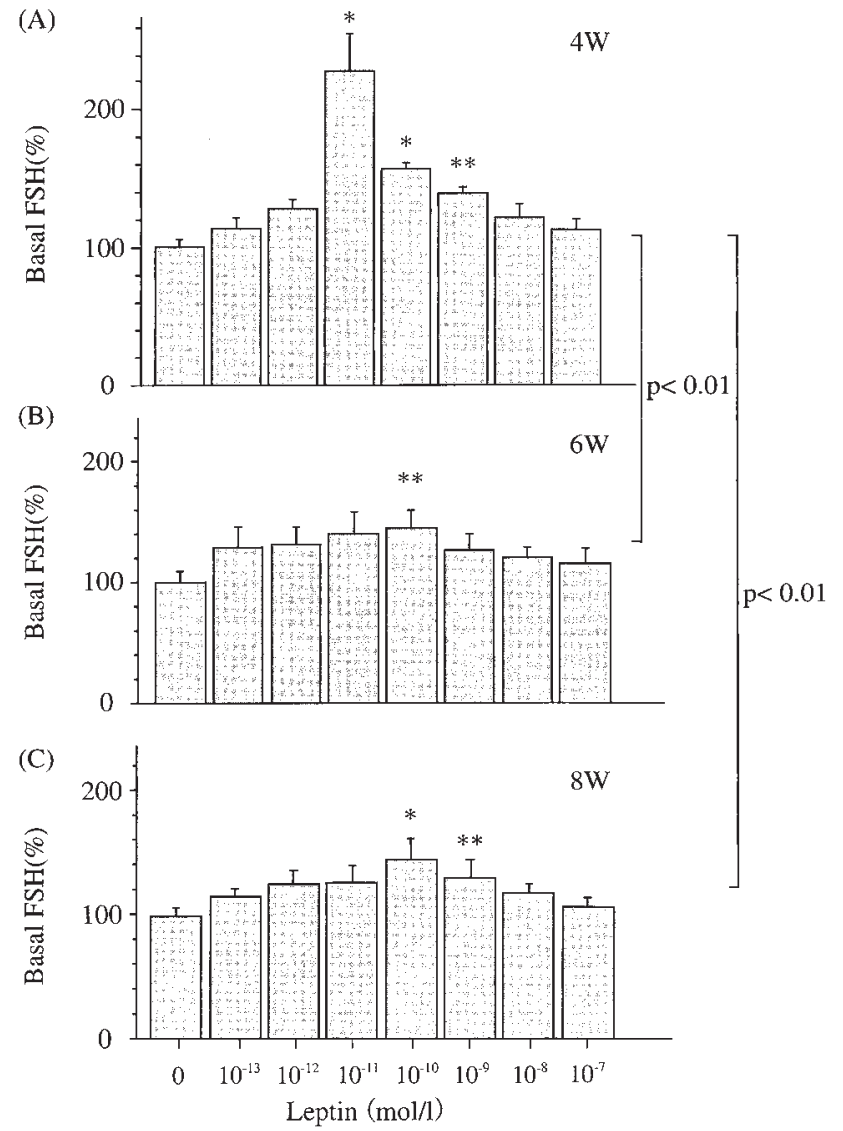

Figure 2 Effects of leptin $\left(0-10^{-7} \mathrm{~mol} / \mathrm{l}\right)$ on basal FSH secretion from pituitary cells incubated in vitro for $24 \mathrm{~h}(n=8)$. (A) Fourweek-old cells. Basal FSH levels exhibited a bell-shaped doseresponse curve. The control level of FSH (leptin free) was 69.0 \pm 2.18 (mean \pm S.E.M.) IU/I. The peak level increased as the concentration of leptin increased to $10^{-11} \mathrm{~mol} / \mathrm{l}(224 \% ; P<0.01 \mathrm{vs} \mathrm{con-}$ trol). (B) Six-week-old cells. (C) Eight-week-old cells. FSH levels in these two groups also exhibited bell-shaped dose-response curves. The control levels of FSH (leptin free) in 6-week-old and 8 -week-old cells were $36.7 \pm 4.14$ and $60.6 \pm 2.18$ (means \pm S.E.M.) IU/I respectively. They increased as the concentration of leptin increased reaching a peak value at a concentration of $10^{-10} \mathrm{~mol} / \mathrm{l}$ (139 and $147 \%$ respectively; $P=0.02, P<0.01$ vs control). It was observed that the peak changed from $10^{-11} \mathrm{~mol} / \mathrm{l}$ to $10^{-10} \mathrm{~mol} / \mathrm{l}$ at the time of puberty onset. There were significant differences in the shape of the curves between $(A)$ and $(B)$ and between $(\mathrm{A})$ and $(\mathrm{C})$ (both $P<0.01$ by two-way ANOVA). Results are expressed as percentage of the control value (mean \pm S.E.M.); ${ }^{\star} P<0.01,{ }^{* \star} P<0.05$.

\section{Effects of leptin on intracellular LH and FSH content in 4-week-old pituitary cells}

Intracellular LH content in 4-week-old pituitary cells after 24-h treatment with leptin increased in accordance with increased leptin concentrations up to $10^{-11} \mathrm{~mol} / \mathrm{l}(194 \%, P<0.05$ vs control), but these effects diminished at higher concentrations of leptin (Fig. 3A) producing a bell-shaped dose-response curve.

Similar results were observed for intracellular FSH content (Fig. 3B). 


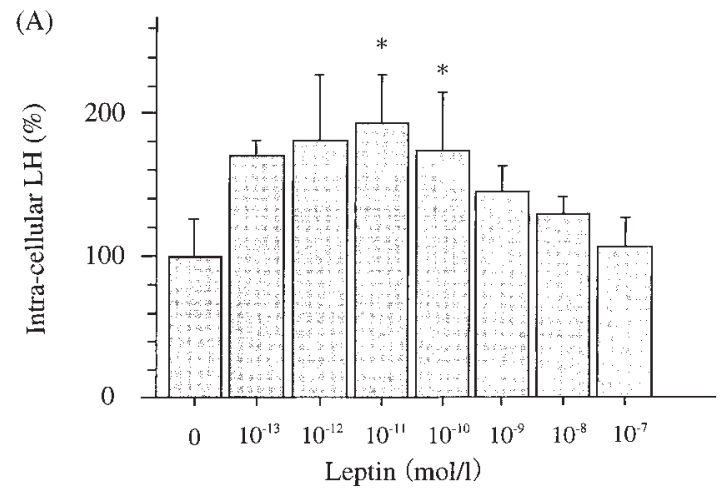

(B)

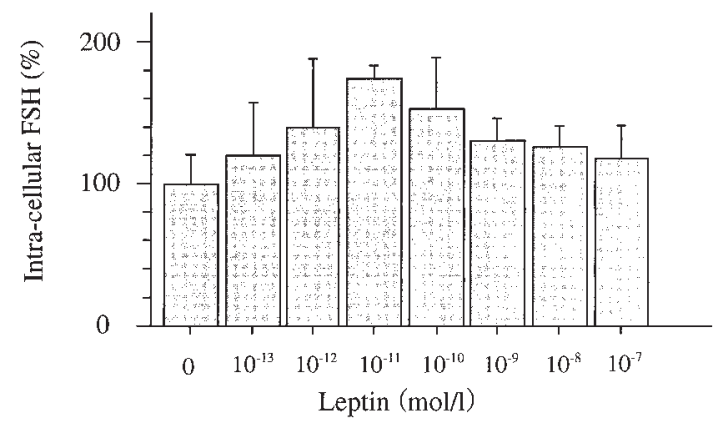

Figure 3 Effects of leptin $\left(0-10^{-7} \mathrm{~mol} / \mathrm{l}\right)$ on intracellular $\mathrm{LH}$ and FSH content in 4-week-old pituitary cells incubated in vitro for $24 \mathrm{~h}(n=8)$. (A) LH level exhibited a bell-shaped dose-response curve. The control level of LH (leptin free) was 66.8 $17.8 \mathrm{IU} / \mathrm{I}$. The $\mathrm{LH}$ level increased as the concentration of leptin increased to $10^{-11} \mathrm{~mol} / \mathrm{l}(194 \% ; P<0.05$ vs control). (B) FSH level also exhibited a bell-shaped dose-response curve. The control level of FSH (leptin free) was 22.8 $\pm 4.36 \mathrm{IU} / \mathrm{I}$. The FSH level increased as the concentration of leptin increased to $10^{-11} \mathrm{~mol} / \mathrm{l}(176 \% ; P<0.05$ vs control). Results are expressed as percentage of the control value (mean \pm S.E.M.); ${ }^{\star} P<0.05$.

\section{Effects of leptin on the GnRH-stimulated LH and FSH secretion from 4-week-old pituitary cells}

We examined the secretion of LH and FSH stimulated by GnRH $\left(10^{-8} \mathrm{~mol} / \mathrm{l}\right)$ in 4 -week-old pituitary cells (Table 1). These cells showed a good response to GnRH. LH and FSH secretion increased under GnRH stimulation by twenty and fifteen times respectively.

Table $1 \mathrm{LH}$ and FSH secretion from cultured 4-week-old pituitary cells incubated in vitro for $4 \mathrm{~h}$ without $(-)$ or with $(+) \mathrm{GnRH}$ $\left(10^{-8} \mathrm{~mol} / \mathrm{l}\right)$. Results are means \pm S.E.M. $(n=8$ in each group $)$.

\begin{tabular}{lrr}
\hline & GnRH $(-)$ & \multicolumn{1}{c}{ GnRH $(+)$} \\
\hline LH (IU/I) & $4.97 \pm 0.64$ & $101.73 \pm 13.31^{*}$ \\
FSH (IU/I) & $14.28 \pm 0.70$ & $214.15 \pm 13.90^{*}$ \\
\hline${ }^{*} P<0.01$. & &
\end{tabular}

www.eje.org
Moreover, GnRH-stimulated LH and FSH secretion increased as leptin concentrations increased up to $10^{-11} \mathrm{~mol} / \mathrm{l}(170 \%$ and $135 \%$ respectively; $P<0.01$ vs control). However, these effects decreased at higher concentrations of leptin. GnRH-stimulated LH and FSH secretion in 4-week-old pituitary cells also exhibited bell-shaped dose-response curves (Fig. 4A, B).

\section{Discussion}

It is commonly thought that the onset of puberty requires good nutritional condition. Puberty occurs when body weight reaches a so-called critical weight $(2,3)$. It is likely that leptin is one of the critical factors that triggers the onset of puberty because leptin from adipose tissue may inform the hypothalamus and the pituitary that the energy store has reached an appropriate level for reproduction.

In ob/ob mice which lack leptin secretion and show obesity and anovulation, chronic leptin treatment not only reduces food intake and body weight but also restores puberty and fertility $(13,14)$. It is also well known that extreme weight loss or gain due to intense exercise, malnutrition or overfeeding disturbs reproductive function and causes infertility in both rodents and humans. In normal adult female rats, LH pulsatility was suppressed by anti-leptin serum (15), suggesting that leptin stimulates hypothalamic GnRH pulsatility. In the adult rat pituitary, leptin produces a dose-related increase in LH and FSH at low/normal concentrations (9), but not at high concentrations $(9,16)$. Therefore, it is assumed that leptin also stimulates the pituitary, and that excessive leptin concentration also interferes with reproductive function. For example, hyperleptinemia caused by extreme obesity may disrupt pituitary function and impair gonadotropin secretion during the peripubertal and postpubertal period in humans (17). Our data showing bell-shaped dose-response curves in gonadotropin secretion stimulated by leptin support these findings.

Body weight of rats increases with age. Serum leptin levels also increase in parallel with age and body weight, and serum concentrations of estradiol begin to rise at 6 weeks of age in rats (11). Vaginal opening and follicular growth of female rats also appear from 5 to 6 weeks of age (18). Therefore, it is considered that 6 weeks of age corresponds to the pubertal period. In addition, 4 and 8 weeks of age correspond to the juvenile and the mature period respectively. According to our previous report, physiological serum leptin levels of female rats was $10^{-10} \mathrm{~mol} / \mathrm{l}$ in pubertal 6-week-old rats, and $10^{-11} \mathrm{~mol} / \mathrm{l}$ in juvenile 4-weekold rats.

Leptin stimulates LH and FSH secretion from cultured female rat pituitary cells, and these effects show a bell-shaped dose-response curve. In this study, we demonstrate that leptin concentrations able 
(A)

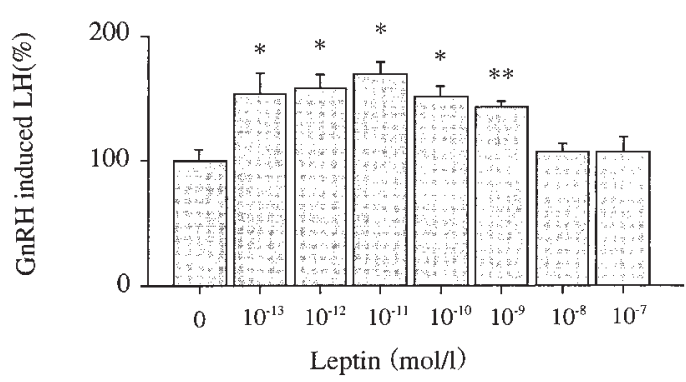

(B)

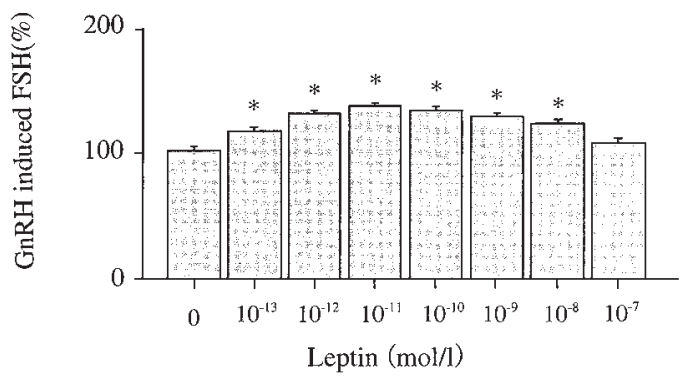

Figure 4 Effects of leptin $\left(0-10^{-7} \mathrm{~mol} / \mathrm{l}\right)$ on $\mathrm{GnRH}$-stimulated $\mathrm{LH}$ and FSH secretion in 4-week-old pituitary cells incubated in vitro for $4 \mathrm{~h}\left(\mathrm{GnRH}: 10^{-8} \mathrm{~mol} / \mathrm{I}\right)(n=8)$. (A) LH level exhibited a bellshaped dose-response curve. The control level of LH (leptin free) was $101.7 \pm 13.3 \mathrm{IU} / \mathrm{l}$. The $\mathrm{LH}$ level increased as the concentration of leptin increased to $10^{-11} \mathrm{~mol} / \mathrm{l}(170 \% ; P<0.01 \mathrm{vs}$ control). (B) FSH level also exhibited a bell-shaped dose-response curve. The control level of FSH (leptin free) was 214.2 $\pm 13.9 \mathrm{IU} / \mathrm{l}$. The FSH level increased as the concentration of leptin increased to $10^{-11} \mathrm{~mol} / \mathrm{l}(135 \% ; P<0.01 \mathrm{vs}$ control). Results are expressed as percentage of the control value (mean \pm S.E.M.); ${ }^{*} P<0.01$, ${ }^{\star *} P<0.05$

to stimulate gonadotropin secretion were similar to the circulating leptin levels at 4 weeks old $\left(10^{-11} \mathrm{~mol} / \mathrm{l}\right)$, and at 6 and 8 weeks old $\left(10^{-10} \mathrm{~mol} / \mathrm{l}\right)$. The changes in circulating serum leptin concentrations around puberty suggest a physiological role of leptin in modulating pituitary gonadotroph cell sensitivity from the juvenile to the mature period of animal life.

In normal girls, serum leptin levels increase before the rise of reproductive hormones which are related to puberty $(5,6,19)$. In juvenile female mice, injection of leptin induced earlier maturation of the reproductive system (20-23). In our study, leptin stimulated the secretion of gonadotropin in juvenile 4-week-old rats. These findings suggest that leptin plays a physiological role in the juvenile period.

In the pituitary, the production of gonadotropin might be induced both directly and indirectly through modification of the sensitivity to GnRH. In the present study, juvenile pituitary cells of 4-week-old rats showed a good response to leptin at a concentration equivalent to the circulating juvenile serum level, with or without GnRH. In fact, GnRH secretion is rarely seen in 4-week-old rats. In the juvenile period, leptin may render gonadotrophs ready to be stimulated by even small amounts of GnRH.

Leptin receptors are expressed all over the body (24), including the pituitary (25). However, taking into account possible differences in density of leptin receptors, leptin may mainly affect the hypothalamus rather than the pituitary. Apparently, initiation of $\mathrm{GnRH}$ secretion is an important factor for puberty onset. Leptin may exert actions on the GnRH neuron modifying the frequency and magnitude of $\mathrm{GnRH}$ pulses directly or indirectly through induction of nitric oxide or suppression of neuropeptide Y (2630). The role of leptin may be more important in the hypothalamus than in the pituitary during the pubertal period.

In conclusion, we demonstrate that leptin acts directly on pituitary cells even in the juvenile period before the occurrence of $\mathrm{GnRH}$ secretion. The maximum effects of leptin on gonadotrophs is manifest at physiological serum concentrations from the juvenile to the mature period. The present data suggest that leptin stimulates the secretion of gonadotropins and modulates the response of the pituitary in the juvenile period before puberty until the appearance of GnRH secretion which strongly drives the hypothalamuspituitary-gonadal axis in the pubertal period.

\section{References}

1 Grumbach MM \& Styne DM. Puberty: ontogeny, neuroendocrinology, physiology, and disorders. In William's Textbook of Endocrinology, pp 1139-1221. Eds JD Wilson \& DM Foster. Philadelphia: Saunders, 1992.

2 Kennedy GC. Body weight and intake as initiating factors for puberty in the rat. Journal of Physiology 1963166 408-418.

3 Frisch RE \& Revelle R. Height and weight at menarche and hypothesis of critical body weights and adolescent events. Science $1970169397-399$.

4 Zhang Y, Proenca R, Maffel M, Barone M, Leopold L \& Friedman JM. Positional cloning of the mouse obese gene and its human homologue. Nature 1994372 425-432.

5 Blum WF, Englaro P, Hanitsch S, Juul A, Hertel NT, Müller J et al. Plasma leptin levels in healthy children and adolescents: dependence on body mass index, body fat mass, gender, pubertal stage and testosterone. Journal of Clinical Endocrinology and Metabolism 199782 2904-2910.

6 Carlsson B, Ankarberg C, Rosberg S, Norjavaara E, AlbertssonWikland K \& Carlsson LMS. Serum leptin concentrations in relation to pubertal development. Archives of Disease in Childhood 199777 396-400.

7 Frederich RC, Hamann A, Anderson S, Lollmann B, Lowell BB \& Flier JS. Leptin levels reflect body lipid content in mice: evidence for diet-induced resistance to leptin action. Nature Medicine 1995 1 1311-1314.

8 Maffei M, Halaas J, Ravussin E, Pratley RE, Lee GH, Ranganathan $\mathrm{S}$ et al. Leptin levels in human and rodent: measurement of plasma leptin and ob RNA in obese and weight-reduced subjects. Nature Medicine 19951 1155-1161.

$9 \mathrm{Yu}$ WH, Kimura M, Walczewska A, Karanth S \& McCann SM. Role of leptin in hypothalamic-pituitary function. PNAS 1997 94 $1023-1028$ 
10 Aubert ML, Pierroz DD, Gruaz NM, d'Alleves V, Vuagnat BA, Sizonenko PC et al. Metabolic control of sexual function and growth. Molecular and Cellular Endocrinology $1998 \mathbf{1 4 0}$ 107-113.

11 Ogura K, Irahara M, Kiyokawa M, Tezuka M, Matsuzaki T, Aono T et al. Effects of leptin on secretion of LH and FSH from primary cultured female rat pituitary cells. European Journal of Endocrinology $2001144653-658$.

12 Kanematsu T, Irahara M, Miyake T, Shitsukawa K \& Aono T. Effect of insulin-like growth factor I on gonadotropin release from the hypothalamus-pituitary axis in vitro. Acta Endocrinologica $1991125227-233$.

13 Barash IA, Cheung CC, Weigle DS, Ren H, Kabigting EB, Kuijper JL et al. Leptin is a metabolic signal to the reproductive system. Endocrinology $19961373144-3147$.

14 Chehab FF, Lim ME \& Lu R. Correction of the sterility defect in homozygous obese female mice by treatment with the human recombinant leptin. Nature Genetics 199612 318-320.

15 Carro E, Pinilla L, Seoane LM, Considine RV, Aguilar E, Casanueva FFet al. Influence of endogenous leptin tone on the estrous cycle and luteinizing hormone pulsatility in female rats. Neuroendocrinology $199766375-377$.

16 Tena-Sempere M, Pinilla L, González LC, Navarro J, Diéguez C, Casanueva FF et al. In vitro pituitary and testicular effects of the leptin-related synthetic peptide leptin (116-130) amide involve actions both similar to and distinct from those of the native leptin molecule in the adult rat. European Journal of Endocrinology 2000142 406-410.

17 Bouvattier C, Lahlou N, Roger M \& Bougnères P. Hyperleptinaemia is associated with impaired gonadotropin response to $\mathrm{GnRH}$ during late puberty in obese girls, not boys. European Journal of Endocrinology 1998138 653-658.

18 Meijs-Roelofs HM, Kramer P, Van Cappellen WA \& Van Leeuwen EC. Effects of a luteinizing hormone-releasing hormone antagonist in late-juvenile female rat. Biology of Reproduction $1990 \mathbf{4 3}$ 607-613.

19 Garcia-Mayor RV, Andrade MA, Rios M, Lage M, Dieguez C \& Casanueva FF. Serum leptin levels in normal children: relationship to age, gender, body mass index, pituitary-gonadal hormones and pubertal stage. Journal of Clinical Endocrinology and Metabolisn $1997822849-2855$.
20 Ahima RS, Prabakaran D, Mantzoros C, Qu D, Lowell B, MaratosFlier $\mathrm{E}$ et al. Role of leptin in the neuroendocrine response to fasting. Nature $1996 \mathbf{3 8 2} 250-252$.

21 Cheung CC, Thornton JE, Kuijper JL, Weigle DS, Clifton DK \& Steiner RA. Leptin is a metabolic gate for the onset of puberty in the female rat. Endocrinology 1997138 855-858.

22 Chehab FF, Mounzih K, Lu R \& Lim ME. Early onset of reproductive function in normal female mice treated with leptin. Science $199727588-90$.

23 Ahima RS, Dushay J, Flier SN, Prabakaran D \& Flier JS. Leptin accelerates the onset of puberty in normal female mice. Journal of Clinical Investigation $199799391-395$.

24 Tartaglia LA, Dembski M, Weng X, Deng N, Culpepper J, Devos R et al. Identification and expression cloning of a leptin receptor, OB-R. Cell 199583 1263-1271.

25 Zamorano PL, Mahesh VB, De Sevilla LM, Chorich LP, Bhat GK \& Brann DW. Expression and localization of the leptin receptor in endocrine and neuroendocrine tissues of the rat. Neuroendocrinology $199765223-228$.

26 Stephens TW, Basinski M, Bristow PK, Bue-Valleskey JM, Burgett SG, Craft L et al. The role of neuropeptide $\mathrm{Y}$ in the antiobesity action of the obese gene product. Nature 1995377 530-532.

27 Schwartz MW, Seeley RJ, Campfield LA, Burn P \& Baskin DG. Identification of targets of leptin action in rat hypothalamus. Journal of Clinical Investigation 199698 1101-1106.

$28 \mathrm{Yu}$ WH, Walczewska A, Karanth S \& McCann SM. Nitric oxide mediates leptin-induced luteinizing hormone-releasing hormone (LHRH) and LHRH and leptin-induced LH release from the pituitary gland. Endocrinology 1997138 5055-5058.

29 Hakansson M-L, Brown H, Ghilardi N, Skoda RC \& Meister B. Leptin receptor immunoreactivity in chemically defined target neuron of the hypothalamus. Journal of Neuroscience $1998 \mathbf{1 8}$ 559-572.

30 Magni P, Vettor R, Pagano C, Calcagno A, Beretta E, Messei E et al. Expression of a leptin receptor in immortalized GnRH-secreting neurons. Endocrinology $19991401581-1585$.

Received 28 June 2001

Accepted 23 October 2001 